Studia nad Autorytaryzmem i Totalitaryzmem 43, nr 4 Wrocław 2021

https://doi.org/10.19195/2300-7249.43.4.26

\author{
MARTA KŁOPOCKA-JASIŃSKA \\ ORCID: 0000-0001-9205-4353 \\ Uniwersytet Wrocławski \\ marta.klopocka-jasinska@uwr.edu.pl
}

\title{
Czy państwo może decydować o miejscu pochówku dyktatora? Komentarz do postanowienia hiszpańskiego Trybunału Konstytucyjnego z 17 października 2019 roku w sprawie ekshumacji szczątków Francisca Franco Bahamondego
}

Słowa kluczowe: ekshumacja, przeniesienie grobu, dyktator Francisco Franco Bahamonde, Dolina Poległych, prawo do ochrony życia prywatnego i rodzinnego.

\author{
CAN THE STATE DECIDE WHERE A DICTATOR IS BURIED? \\ REMARKS ON THE RULING OF THE SPANISH CONSTITUTIONAL COURT \\ OF 17 OCTOBER 2019 ON THE EXHUMATION OF FRANCISCO FRANCO \\ BAHAMONDE'S REMAINS
}

\begin{abstract}
This article comments on the Spanish Constitutional Court's order of 17 October 2019, ATC 119/2020, regarding the exhumation and transfer of the remains of Francisco Franco Bahamonde from the Valley of the Fallen. Franco's relatives brought a constitutional complaint before the Constitutional Court against the resolutions of the Council of Ministers of 15 February and 15 March 2019, which concerned the exhumation of the dictator's remains and their transfer to the Mingorrubio Cemetery in El Pardo. This was done against the wishes of the family, who had indicated another location. The applicants submitted, inter alia, that their right to respect for private and family life had been violated. In fact, certain issues relating to the treatment of the body of a deceased person fall within the scope of the right to privacy. However, the Spanish Court did not accept the applicants' plea and held that there was no violation of the constitutional right. It justified its decision on the grounds that the right to protection of private and family life is not absolute and is subject to limitations, and that the measures applied in this case were in line with a "constitutionally legitimate aim," proportionate and necessary. The Court's decision is correct, although its reasoning leaves much to be desired. The Court could have strengthened its argumentation with, first, a more in-
\end{abstract}


depth analysis of proportionality, and, second, with reference to Strasburg standards. In particular, as the Court pointed out, the historical and political importance of the person at the head of the political regime established after the civil war and acting as head of state meant that the decision on where to bury his remains went beyond the dimension of an individual private matter.

Keywords: exhumation, transfer of grave, dictator Francisco Franco Bahamonde, Valley of the Fallen, right to respect for private and family life.

Postanowieniem z 17 października 2019 roku ${ }^{1}$ Sekcja I hiszpańskiego Trybunału Konstytucyjnego odrzuciła skargę konstytucyjną wniesioną przez krewnych generała Franco przeciwko uchwałom Rady Ministrów z dnia 15 lutego i 15 marca 2019 roku oraz wyrokowi Izby Sądowo-Administracyjnej Sądu Najwyższego z dnia 30 września 2019 roku $^{2}$. Trybunał przyjął, że w sprawie nie doszło do naruszenia prawa, które stanowi przesłankę dopuszczalności skargi konstytucyjnej na podstawie art. 43 ustawy organicznej o Trybunale Konstytucyjnym (dalej: UOTK) ${ }^{3}$. Skarga konstytucyjna (recurso de amparo constitucional) z art. 43 UOTK przysługuje $\mathrm{w}$ przypadku naruszenia określonych w konstytucji praw podstawowych, spowodowanych przez akty władzy wykonawczej ${ }^{4}, \mathrm{w}$ tym wypadku uchwały Rady Ministrów, pod warunkiem wyczerpania odpowiedniej drogi sądowej. Ten ostatni wymóg Trybunał uznał za spełniony w związku z zakończonym postępowaniem przed Sądem Najwyższym, które zainicjowali skarżący. Zaskarżone w drodze skargi konstytucyjnej uchwały Rady Ministrów dotyczyły przeprowadzenia ekshumacji szczątków Francisca Franco Bahamondego w celu przeniesienia ich z Doliny Poległych (Valle de los Caídos) i pochowania na cmentarzu w Mingorrubio w El Pardo, gdzie spoczywa małżonka dyktatora. Wyrok Sądu Najwyższego potwierdzający ich legalność nie był rozpatrywany przez Trybunał jako odrębny przedmiot skargi, ale jedynie jako przesłanka jej dopuszczalności, ustanowiona w art. 43 UOTK. Trybunał uznał bowiem, że skarżący kwestionują go jedynie $\mathrm{w}$ takim zakresie, $\mathrm{w}$ jakim nie doprowadził on do naprawienia naruszeń praw podstawowych wywołanych przez decyzje władzy wykonawczej.

Analizę rozstrzygnięcia hiszpańskiego Trybunału Konstytucyjnego warto poprzedzić przedstawieniem polskiemu czytelnikowi faktycznego stanu sprawy. Uchwałą z 31 sierpnia 2018 roku Rada Ministrów rozpoczęła postępowanie

1 Postanowienie TK Królestwa Hiszpanii z 17 października 2019 roku, sygn. akt ATC 119/2020, ECLI:ES:TC:2019:119A.

2 Wyrok SN Królestwa Hiszpanii z 30 września 2019 roku, sygn. akt STS 2834/2019, ECLI: Es:Ts:2019:2834, https://www.poderjudicial.es/search/openDocument/c8a2fa5486ced8af (dostęp: 30.09.2021).

${ }^{3}$ Ley Orgánica 2/1979, de 3 de octubre, del Tribunal Constitucional, Dziennik Urzędowy Państwa (Boletín Oficial de Estado - BOE) z 5 października 1979 r. Nr 239, s. 23186.

${ }^{4} \mathrm{~W}$ art. 43 ust. 1 UOTK mowa jest o przepisach, aktach prawnych, zaniechaniach lub zwykłych działaniach faktycznych rządu, jego organów lub urzędników albo kolegialnych organów wykonawczych wspólnot autonomicznych czy też ich organów, urzędników bądź przedstawicieli. 
w sprawie ekshumacji i przeniesienia szczątków Francisca Franco, stosownie do przepisu art. 16 ust. 3 ustawy z 26 grudnia 2007 roku o uznaniu i rozszerzeniu praw oraz ustanowieniu środków na rzecz osób, które doznały prześladowań bądź przemocy podczas wojny domowej i w okresie dyktatury (dalej: ustawy $\mathrm{nr} 52 / 2007)^{5}$. Przepis ten wraz z postanowieniem dodatkowym szóstym bis (disposición adicional sexta bis), ustanawiającym postępowanie w celu zagwarantowania jego realizacji, został dodany do tego aktu na mocy królewskiego dekretu-ustawy ${ }^{6} \mathrm{nr}$ 10/2018 z 24 sierpnia 2018 roku$^{7}$. Zgodnie z art. 16 ust. 3 ustawy nr 52/2007 w Dolinie Poległych, jako miejscu upamiętnienia i hołdu wobec ofiar hiszpańskiej wojny domowej, mogą spoczywać wyłącznie szczątki osób zmarłych w wyniku tych walk. Z kolei przepis dodatkowy szósty bis nakłada na rząd obowiązek zapewnienia wykonania art. 16 ust. 3 wspomnianej ustawy „w warunkach odpowiadających godności i z szacunkiem". W tym celu upoważnia on rząd do przeprowadzenia uzasadnionej pilnym i wyjątkowym interesem publicznym, a także użytecznością publiczną i interesem społecznym, natychmiastowej ekshumacji i przeniesienia szczątków osób zmarłych, innych niż te, o których mowa w art. 16 ust. 3 ustawy nr 52/2007. Ustanawia on również procedurę przeprowadzenia ekshumacji i przeniesienia zwłok. Decyzję w tej sprawie podejmuje w drodze uchwały Rada Ministrów, która też wszczyna postępowanie z urzędu. W uchwale o wszczęciu procedury ekshumacyjnej Rada Ministrów wskazuje organ właściwy do przeprowadzenia postępowania oraz termin piętnastu dni, w ciągu których mają się stawić i przedstawić swoje stanowisko zainteresowane osoby. Krewni mogą w tym czasie określić nowe miejsce pochówku oraz przedstawić niezbędne do tego dokumenty i stosowne pozwolenia. W razie braku zgody wśród rodziny albo w przypadku niewskazania takiego miejsca w odpowiednim terminie i formie, o miejscu pochowania szczątków rozstrzyga Rada Ministrów, mając na względzie zapewnienie godnego pogrzebu. Ustawa uprawnia Radę Ministrów do wykonania stosownych czynności w związku z przeprowadzeniem ekshumacji i przeniesieniem szczątków, w tym wyznaczenia ministra właściwego do spraw wymiaru sprawiedliwości, który zwróci się do odpowiednich organów administracji lokalnej w sprawie projektu niezbędnego do przeprowadzenia ekshumacji

5 Ley 52/2007, de 26 de diciembre, por la que se reconocen y amplian derechos y se establecen medidas en favor de quienes padecieron persecución o violencia durante la guerra civil y la dictadura, Dziennik Urzędowy Państwa z 27 grudnia 2007 r. Nr 310, s. 53410.

${ }^{6}$ Królewski dekret-ustawa (decreto-ley) to rodzaj aktu normatywnego wydawanego przez rząd w ramach tak zwanego ustawodawstwa delegowanego, zgodnie z art. 86 Konstytucji Hiszpanii. Szerzej na temat dekretów-ustaw zob. na przykład E. Espín Templado, [w:] Derecho constitucional, vol. 1. El ordenamiento constitucional. Derechos y deberes de los ciudadanos, ed. L. López Guerra et al., Valencia 2013, s. 84 n. oraz M. Pulido Quecedo, La Constitución Española con la Jurisprudencia del Tribunal Constitucional, Pamplona 1996, s. 1315 n. W polskim piśmiennictwie zob. T. Mołdawa, System konstytucyjny Hiszpanii, Warszawa 2012, s. 101.

7 Dziennik Urzędowy Państwa z 25 sierpnia 2018 r. Nr 206. 
oraz sporządzenia raportu. Ostateczna decyzja o realizacji ekshumacji i przeniesieniu zwłok do ustalonego miejsca należy do Rady Ministrów.

W analizowanej sprawie organ ten uchwałą $\mathrm{z}$ dnia 15 lutego 2019 roku podjął decyzję o ekshumacji szczątków Francisca Franco z Bazyliki Świętego Krzyża w Dolinie Poległych i wyznaczeniu jego krewnym piętnastodniowego terminu na ustalenie innego niż zaproponowana przez nich krypta w madryckiej katedrze Almudena miejsca pochówku ${ }^{8}$. Wobec niewskazania alternatywnego miejsca pochówku ${ }^{9}$ Rada Ministrów w drodze uchwały z 15 marca 2019 roku ustaliła, że szczątki Francisca Franco zostaną pochowane na cmentarzu w El Pardo-Mingorrubio, oraz wyznaczyła dzień przeprowadzenia ekshumacji, przeniesienia szczątków i pogrzebu na 10 czerwca tego samego roku. Obie uchwały Rady Ministrów zostały zaskarżone przez krewnych dyktatora skargą w postępowaniu sądowo-administracyjnym ${ }^{10}$ do Sądu Najwyższego (Tribunal Supremo), a ekshumacja została wstrzymana w ramach zastosowania środków tymczasowych. W dniu 30 września 2019 roku Sąd Najwyższy wydał wyrok oddalający skargę krewnych Franco, potwierdzając zgodność uchwał Rady Ministrów z prawem ${ }^{11}$. Stały się one przedmiotem skargi konstytucyjnej (recurso de amparo constitucional) wniesionej przez rodzinę dyktatora do Trybunału Konstytucyjnego w dniu 10 października 2019 roku. Skarżący podnieśli, że kwestionowane przez nich uchwały Rady Ministrów naruszają zasadę równości w zakresie stosowania ustawy (art. 14 Konstytucji Hiszpanii), prawo do ochrony życia prywatnego i rodzinnego (art. 18 ust. 1 Konstytucji Hiszpanii) w związku z prawem do wolności religijnej (art. 16 ust. 1 Konstytucji Hiszpanii), a także z prawem do skutecznej ochrony sądowej (art. 24 ust. 1 Konstytucji Hiszpanii). Ponadto w ocenie skarżących uchwały Rady Ministrów zostały wydane na podstawie królewskiego dekretu-ustawy 10/2018, który jest niekonstytucyjny z powodu braku przesłanki do jego ustanowienia oraz naruszenia przez ten akt praw podstawowych. $Z$ tego względu krewni generała zwrócili się do Trybunału Konstytucyjnego o wszczęcie postępowania w ramach tak zwanej wewnętrznej kontroli konstytucyjności na podstawie art. 55 ust. 2 UOTK $^{12}$. Zdaniem skarżących naruszenie zasady

${ }^{8}$ Rząd nie zgodził się na pochowanie szczątków Franco w należącej do rodziny krypty w madryckiej katedrze Almudena, powołując się na względy bezpieczeństwa oraz chęć uniknięcia sytuacji, w której miejsce to stałoby się symbolem powstania wojskowego, wojny domowej oraz represji w okresie dyktatury.

${ }^{9}$ Krewni generała Franco zamiast wskazać inne miejsce pochówku złożyli w Kancelarii Rady Ministrów pismo informujące o złożeniu skargi do sądu administracyjnego na decyzję rządu.

${ }^{10} \mathrm{~W}$ języku hiszpańskim: recurso contencioso-administrativo.

11 Wyrok SN Królestwa Hiszpanii z 30 września 2019 roku, sygn. akt STS 1279/2019.

12 Charakterystyczny dla modelu hiszpańskiej skargi konstytucyjnej jest brak możliwości zaskarżenia aktu normatywnego o randze ustawy. Przedmiotem skargi jest bowiem akt organu władzy publicznej o charakterze indywidualnym i konkretnym, naruszający prawa podstawowe skarżącego. Jeżeli jednak okaże się, że przyczyną naruszenia prawa podstawowego jest zastosowanie niekonstytucyjnej normy ustawowej, wówczas skład orzekający (Izba bądź Sekcja) przedstawia tę kwestię do 
równości w zakresie stosowania ustawy, polegało na nieuzasadnionym uznaniu „preferencyjnego” charakteru ekshumacji szczątków Francisca Franco Bahamondego, które nie miało obiektywnych podstaw, a opierało się jedynie na dyskryminujących kryteriach wynikających z warunków osobistych zmarłego, w tym jego przekonań oraz politycznego znaczenia. Skarżący upatrywali naruszenia prawa do ochrony życia prywatnego i rodzinnego w pozbawieniu ich możliwości decydowania o miejscu pochówku szczątków Franco na mocy decyzji rządu odwołującej się do przesłanki bezpieczeństwa publicznego, z pominięciem mających w tym wypadku zastosowanie przepisów prawnych. Według skarżących doszło w ten sposób również do naruszenia art. 18 ust. 1 łącznie z art. 16 ust. 1 Konstytucji Hiszpanii w takim zakresie, w jakim dotyczą one prawa do wolności religijnej, w tym prawa osoby do pochówku zgodnie ze zwyczajem i praktykami przyjętymi w wyznawanej przez nią religii. Naruszenie prawa do skutecznej ochrony sądowej skarżący powiązali z naruszeniem art. 18 ust. 1 Konstytucji Hiszpanii, podnosząc, że nastąpiło ono poprzez uniemożliwienie im wskazania alternatywnego miejsca pochówku w przewidzianym ustawowo terminie piętnastu dni.

Trybunał Konstytucyjny nie przychylił się do zarzutów skarżących, stwierdzając oczywisty brak naruszenia przywołanych w skardze praw podstawowych. Warto odnotować, że rozstrzygnięcie Trybunału zapadło w formie postanowienia (auto), a nie, jak stanowi ustawa, w formie zarządzenia (providencia), gdyż organ ten uznał, że omawiana sprawa $z$ uwagi na jej znaczenie społeczne i polityczne uzasadnia przyjęcie tej formy, tak by opinia publiczna mogła poznać motywy rozstrzygnięcia ${ }^{13}$. Trybunał zwrócił uwagę, że historyczne i polityczne znaczenie osoby Francisca Franco Bahamondego, stojącego na czele ustanowionego po wojnie domowej reżimu oraz pełniącego funkcję szefa państwa, sprawia, że decyzja dotycząca miejsca pochówku jego szczątków wykracza poza wymiar indywidualnej sprawy o charakterze prywatnym. Powyższe okoliczności powodują, że wniesiona przez krewnych Franco skarga spełnia warunek, ,szczególnej doniosłości konstytucyjnej”, wymaganej przez art. 50 ust. 1 lit. b) UOTK, a dokładnie, stosownie do ustalonego w orzecznictwie konstytucyjnym katalogu elementów składających się na szczególną doniosłość konstytucyjną: „dotyczy kwestii prawnej o istotnych i powszechnych skutkach społecznych lub gospodarczych lub

rozpoznania przez pełny skład Trybunału, który może orzec o niekonstytucyjności normy ustawowej w odrębnym wyroku według zasad, jakie obowiązują przy rozstrzyganiu w sprawach wniosków o kontrolę konstytucyjności i pytań prawnych. Decyzja o zwróceniu się do plenum o rozstrzygnięcie w sprawie konstytucyjności normy ustawowej należy do organu rozpoznającego skargę. Skarżący może zawrzeć takie żądanie w skardze, jednak nie jest ono dla Trybunału wiążące, podobnie jak jego brak. Szerzej zob: M. Kłopocka-Jasińska, Skarga konstytucyjna w Królestwie Hiszpanii. W poszukiwaniu optymalnej ochrony skargowej, Warszawa 2010, s. 191-194.

13 Zgodnie z art. 50 ust. 3 UOTK w zarządzeniach o odrzuceniu skargi wskazuje się jedynie powód takiej decyzji (warunek dopuszczalności, który nie został spełniony). Ustawa stanowi też, że od zarządzeń o odrzuceniu skargi stronie nie przysługuje zażalenie. Może ono natomiast zostać zaskarżone przez prokuraturę w formie tak zwanej skargi supliki w terminie trzech dni. 
wiąże się z pewnym konsekwencjami politycznymi o charakterze ogólnym" ${ }^{14}$. Spełnienie tej przesłanki, choć wpłynęło na formę, w której zapadło rozstrzygnięcie, nie wystarczyło do uznania skargi za dopuszczalną i przyjęcia jej do merytorycznego rozpoznania.

W uzasadnieniu decyzji Trybunału pojawiło się wiele interesujących wątków zasługujących na omówienie, jednak niniejszy komentarz ograniczę do jednego $\mathrm{z}$ nich, a mianowicie do problemu naruszenia prawa do ochrony życia prywatnego i rodzinnego w związku z ekshumacją zmarłego, przeprowadzoną wbrew woli bliskich, i decyzją władz o miejscu pochówku. Jest to o tyle usprawiedliwione, że akurat ten zarzut był trafny z perspektywy ingerencji państwa w prawo skarżących, kluczowa była zatem odpowiedź na pytanie, czy ingerencja ta była zgodna $\mathrm{z}$ prawem i proporcjonalna. Zagadnienie to jest interesujące także $\mathrm{z}$ tego powodu, że skarżący zdecydowali się na wniesienie skargi indywidualnej do Europejskiego Trybunału Praw Człowieka (dalej: ETPCz) ${ }^{15}$. W tej chwili nie ma informacji o stanie rozpatrywania tej sprawy, choć wcześniej strasburski trybunał odmówił zastosowania środków tymczasowych w tej sprawie, mających doprowadzić do wstrzymania ekshumacji ${ }^{16}$. Warto zatem spojrzeć na ten problem z perspektywy orzecznictwa ETPCz i art. 8 Konwencji o ochronie praw człowieka, tym bardziej że w ostatnim czasie zostały wydane bezprecedensowe wyroki dotyczące ekshumacji w sprawach Solska, Rybicka v. Polska ${ }^{17}$ czy Drašković v. Czarnogóra $^{18}$. Oba rozstrzygnięcia wprawdzie zapadły na tle zupełnie innych stanów faktycznych, ale można na ich podstawie próbować zrekonstruować kształtujący się w tym zakresie standard ${ }^{19}$.

Hiszpański Trybunał Konstytucyjny zdecydowanie odrzucił zarzut naruszenia art. 18 ust. $1 \mathrm{w}$ związku $\mathrm{z}$ art. 16 ust. 1 Konstytucji Hiszpanii. Zgodził się, że prawo krewnych do dysponowania szczątkami przodków w związku $\mathrm{z}$ pochówkiem bądź ekshumacją może być rozpatrywane na gruncie prawa do ochrony życia prywatnego i rodzinnego z art. 18 ust. 1 hiszpańskiej ustawy zasadniczej. Jednakże, jak każde prawo podstawowe, podlega ono ograniczeniom,

14 W wyroku z 25 czerwca 2009 roku (sygn. akt STC 155/2009) hiszpański Trybunał Konstytucyjny podjął się wyjaśnienia, w jakich sytuacjach zachodzi „,Szczególna doniosłość konstytucyjna" z art. 50 ust. 1 lit. b UOTK, wskazując siedem wyznaczników (elementów), które mogą uzasadniać wydanie merytorycznego rozstrzygnięcia w sprawie amparo.

15 Franco's grandchildren take Strasbourg a lawsuit for the exhumation of the dictator, https:// spainsnews.com/francos-grandchildren-take-strasbourg-a-lawsuit-for-the-exhumation-of-thedictator/ (dostep: 30.09.2021).

16 European rights court rejects bid to halt Franco's exhumation, https://www.france24.com/en/ 20191017-european-rights-court-rejects-bid-to-halt-franco-s-exhumation (dostęp: 30.09.2021).

17 Solska i Rybicka v. Polska, skargi 30491/17 i 31083/17, wyrok ETPCz z 20 września 2018 roku.

18 Drašković v. Czarnogóra, skarga 40597/17, wyrok ETPCz z 9 września 2020 roku.

19 Szerzej zob. D. Utrilla, On exhumation of human remains: Strasbourg's standards, EU Law Live, 11 czerwca 2020, s. 1 n., https://www.academia.edu/43448767/On_exhumation_of_human_ remains_Strasbourg_s_standards (dostęp: 30.09.2021). 
które muszą być zgodne z „konstytucyjnie legitymowanym celem” oraz spełniać warunek konieczności i adekwatności, „by ten cel osiągnąć"20. W ocenie Trybunału ograniczenie prawa przewidzianego w art. 18 ust. 1 Konstytucji Hiszpanii było uzasadnione konstytucyjnie legitymowanym celem wyrażonym $\mathrm{w}$ art. 1 ustawy 52/2007, takim jak ,eliminowanie elementów podziału między obywatelami, wszystko po to, aby wspierać spójność i solidarność wśród różnych pokoleń Hiszpanów w zgodzie z zasadami, wartościami i wolnościami konstytucyjnymi”. Zdaniem hiszpańskiego TK, aby osiągnąć wspomniany cel, przyjęto proporcjonalne i konieczne środki przewidziane w ustawie 52/2007, których skuteczność zapewniono dzięki procedurze określonej w postanowieniu dodatkowym szóstym bis tejże ustawy. Ponadto, jak zauważył Trybunał, rodzina otrzymała możliwość decydowania o losie szczątków zmarłego poprzez wskazanie miejsca pochówku. Hiszpański strażnik konstytucji nie dopatrzył się również naruszenia prawa do wolności religijnej skarżących, wskazując, że podjęte przez rząd środki zastosowano z poszanowaniem ich wierzeń religijnych, a szczątki Francisca Franco Bahamondego zostały przeniesione na cmentarz katolicki.

W świetle hiszpańskiej ustawy regulującej postępowanie przed Trybunałem Konstytucyjnym nie ma wątpliwości, że z przyczyn proceduralnych sąd ten nie musiał uzasadniać swojej decyzji. Skoro jednak zdecydował się na taki krok, można było wymagać od niego rozbudowania argumentacji w części dotyczącej zarzutu naruszenia prawa do ochrony życia prywatnego skarżących. W sprawie tak wielkiej wagi wyjaśnienie motywów podjętego rozstrzygnięcia jest szczególnie istotne, gdyż opinia publiczna może w ten sposób poznać przesłanki, jakimi kierował się Trybunał, wydając swoją decyzję, a jednocześnie dostarcza się jasnych wskazówek jednostkom i organom władzy publicznej na temat dopuszczalnego zakresu ingerencji władzy ${ }^{21}$. Dzięki klarownemu przedstawieniu argumentów sąd konstytucyjny nie naraża się na zarzut arbitralności, a dodatkowo w pewnym sensie legitymizuje swoje rozstrzygnięcie ${ }^{22}$. Polityczna legitymizacja decyzji sądowych, jak trafnie dostrzega się w piśmiennictwie, zależy od tego, czy argumenty użyte do rozstrzygnięcia sprawy są akceptowalne nawet przez tych, którzy nie zgadzają się z tym rozstrzygnięciem ${ }^{23}$. W ten sposób Trybunał buduje swój autorytet i zaufanie ze strony społeczeństwa ${ }^{24}$. Tymczasem uzasadnienie omawianego rozstrzygnięcia w części dotyczącej naruszenia art. 18 ust. 1 Konstytucji jest dość lakoniczne. Trudno uznać za satysfakcjonujący sposób, w jaki

20 Zob. na przykład wyrok TK Królestwa Hiszpanii z 1 lutego 2016 roku, sygn. akt STC 11/2016, FJ. 3.

21 A. Śledzińska-Simon, Analiza proporcjonalności ograniczeń konstytucyjnych praw $i$ wolności. Teoria i praktyka, Wrocław 2019, s. 241.

22 W. Sadurski, Supranational Public Reason. Part One - A Theory, „Sydney Law School Research Paper" 2015, nr 15/02, s. 11-12, https://ssrn.com/abstract=2553611 (dostęp: 30.09.2021).

23 A. Śledzińska-Simon, op. cit., s. 65 i przywołana tam literatura.

24 O potrzebie budowania przez sądy konstytucyjne zaufania, które nie jest dane raz na zawsze i może zostać zniszczone jedną błędną decyzją, zob. A. Śledzińska-Simon, op. cit., s. 239. 
hiszpański Trybunał odniósł się do poszczególnych przesłanek testu proporcjonalności ${ }^{25}$. Trybunał nie tyle analizę proporcjonalności przeprowadził, co ją ,powołał” czy też „oświadczył” 26 . W zasadzie uzasadnienie sprowadza się do stwierdzenia, że ingerencja była zgodna $z$ legitymowanym celem i przeprowadzona za pomocą proporcjonalnych i koniecznych środków. Potwierdzając dopuszczalność ingerencji, Trybunał skoncentrował się na kwestii zapewnienia krewnym możliwości wyboru miejsca pochówku bliskiej osoby. Nie odniósł się natomiast do faktu, że decyzję w sprawie ekshumacji pozostawiono rządowi, podobnie jak ostateczną decyzję w sprawie miejsca spoczynku generała Franco. W uzasadnieniu zabrakło też moim zdaniem odwołania do orzecznictwa $\mathrm{ETPCz}^{27}$, tym bardziej że hiszpański Trybunał Konstytucyjny w swoich orzeczeniach wielokrotnie podkreślał, że stosownie do art. 10 ust. 2 Konstytucji Hiszpanii doktryna ETPCz stanowi kryterium interpretacji norm konstytucyjnych odnoszących się do wolności i praw podstawowych ${ }^{28}$.

Hiszpański Trybunał mógł zatem wzmocnić przedstawioną argumentację poprzez, po pierwsze, bardziej pogłębioną analizę proporcjonalności, a po drugie, przywołanie standardów strasburskich. Warto przy tym podkreślić, że analiza proporcjonalności jest jedną z metod uzasadniania orzeczeń sądowych; dzięki niej sąd, przechodząc przez kolejne jej etapy, artykułuje swoje racje. Trudno nie podzielać opinii, że jest ona wymagająca dla sędziów, ponieważ wiąże się z niełatwymi pytaniami, na które nie zawsze są w stanie udzielić odpowiedzi ${ }^{29}$. W rezultacie oznacza to, że w niektórych sprawach sędziowie muszą polegać na wiedzy i doświadczeniu innych, w tym na ocenie rządu, szczególnie odpowiadając na pytanie, czy pożądany cel mógłby zostać osiągnięty poprzez złagodzenie prawa lub

25 Zgodnie z utrwalonym orzecznictwem Trybunału Konstytucyjnego Królestwa Hiszpanii ocena legalności i proporcjonalności ingerencji w prawo do ochrony życia prywatnego i rodzinnego wymaga przeprowadzenia testu, na który składają się cztery elementy: 1. czy zastosowany środek ingerencji miał podstawę prawną? 2. czy był adekwatny do zamierzonego celu? 3. czy był konieczny, a więc, czy nie istniał inny mniej dotkliwy, a jednocześnie podobnie skuteczny, środek do osiągnięcia zamierzonego celu? 4. czy był proporcjonalny w ścisłym znaczeniu, a zatem, czy prowadził do zrównoważenia interesów pozostających w konflikcie (przyniósł więcej korzyści dla interesu publicznego niż szkody dla zestawionych z nim innych dóbr lub wartości)? Zob. wyrok TK Królestwa Hiszpanii z 1 lutego 2016 roku, sygn. akt STC 1/2016, BOE z 7 marca 2016 r. Nr 57, ECLI:ES:TC:2016:11 i przywołane tam orzeczenia TK. Zob. też E. Roca Trías, M.A. Ahumada Ruiz, Los principios de razonabilidad y proporcionalidad en la jurisprudencia constitucional española, Rome 2013, s. 12, https://www.tribunalconstitucional.es/es/trilateral/documentosreuniones/37/ponencia\%20espa\%C3\%91a\%202013.pdf (dostęp: 30.09.2021).

${ }^{26}$ Posługuję się tymi terminami za A. Śledzińską-Simon i W. Sadurskim - zob. eadem, op. cit., s. 68; idem, op. cit., s. 12.

27 Takie nawiązanie zawiera uzasadnienie wyroku hiszpańskiego Sądu Najwyższego, który wcześniej rozpoznawał niniejszą sprawę. Zob. wyrok SN Królestwa Hiszpanii z 30 września 2019 roku, sygn. akt STS 2834/2019.

28 Zob. na przykład przywołany wyżej wyrok TK z 1 lutego 2016 roku.

29 Zob. A. Śledzińska-Simon, op. cit., s. 239. 
polityki ${ }^{30}$. W badaniach nad zasadą proporcjonalności zauważa się także, że sądy, stosując analizę proporcjonalności, przesunęły punkt ciężkości na etap ważenia kolidujących wartości, mniej uważnie podchodząc do wcześniejszych części tej procedury ${ }^{31}$. Rzadko więc sądy konstytucyjne uznają, że badane przepisy, polityka lub decyzje nie spełniają testu prawowitego celu i często pomijają test konieczności ${ }^{32}$. Nie wymagałabym zatem od hiszpańskiego Trybunału kontestowania określonego przez ustawodawcę legitymowanego celu czy poszukania najmniej uciążliwych środków do jego realizacji, zwłaszcza w tak trudnej i delikatnej sprawie. Można było jednak oczekiwać od sądu konstytucyjnego dokonania oceny wagi kolidujących ze sobą wartości, a w zasadzie tego, czy władza ustawodawcza i wykonawcza dokonały sprawiedliwego wyważenia racji, przy czym nie chodzi tu o rozstrzygnięcie, czy wprowadzone rozwiązanie jest idealne, ale raczej o to, czy można je zaakceptować $\mathrm{w}$ danych okolicznościach ${ }^{33}$. W tym kontekście królewski dekret-ustawę 10/2018 należy oceniać jako kolejny krok do rozliczenia się przez Hiszpanów z ich trudną przeszłością, podjęty w celu ,demokratyzacji” pamięci o wojnie domowej ${ }^{34}$. Trzeba w tym miejscu podkreślić, że ustawa 52/2007, określana powszechnie jako „ustawa o pamięci historycznej”35, była pierwszą, która miała położyć kres dominacji dotychczas obowiązującej narracji na temat ofiar opresyjnego reżimu. W przeciwieństwie do wcześniejszych ustaw o amnestii z 1939 roku $^{36}$ i z 1977 roku $^{37}$ ustawa 52/2007 odnosiła się do osób będących ofiarami przemocy w czasie wojny domowej i dyktatury. Według Michaela Humphreya ustawę od wcześniejszych aktów odróżniało podejście do statusu ofiary jako kogoś, kto doświadczył naruszeń praw człowieka (victims of human rights abuse ${ }^{38}$. Ustawa 52/2007 ustanowiła nowe prawo podmiotowe do pamięci osobistej i rodzinnej (individual right to personal and family memory) ${ }^{39}$ oraz poszerzyła krąg

30 Ibidem, s. 239 i przywołana tam literatura.

31 Ibidem. W hiszpańskim piśmiennictwie wskazuje się, że w przypadku środków określonych na poziomie ustawy dyskusyjna jest kwestia, czy Trybunał jest w stanie określić, który alternatywny środek jest możliwy do zastosowania, albo oceniać trafność wyboru dokonanego przez ustawodawcę. Zob. E. Roca Trías, M.A. Ahumada Ruiz, op. cit., s. 15.

32 A. Śledzińska-Simon, op. cit., s. 239.

33 Ibidem, s. 245.

34 M. Humphrey, Law, Memory and Amnesty in Spain, „Macquarie Law Journal” 2014, nr 13, s. 26, baza HeinOnline, https://heinonline.org/HOL/P?h=hein.journals/macq13\&i=33 (dostęp: 7.12. 2020).

35 J. Chaves-Palacios, Consecuencias del franquismo en la España democrática: legislación, exhumaciones de fosas y memoria, „Historia Contemporánea” 2019, nr 60, s. 521.

${ }^{36}$ Ley de 23 septiembre 1939 por la cual se consideraban como no delictivos determinadas actuaciones políticas sociales desarrolladas desde el 14 de abril de 1931 hasta el 18 de julio de 1936., BOE z dnia 30 września 1939 r. Nr 278.

37 Ley 46/1977, de octubre, de Amnistía, BOE z dnia 17 października 1977 r. Nr 248.

38 M. Humphrey, op. cit., s. 26.

39 Zob. ibidem, s. 35. 
osób uznanych za ofiary frankistowskiego reżimu ${ }^{40}$. M. Humphrey twierdzi też, że wspomniany akt przerwał panującą w kraju ciszę na temat skali represji, dopuszczając do głosu tych, którzy ucierpieli, a przez to zakwestionował konsensus ustalony na mocy ustawy z 1977 roku. Jego słabością było jednak to, że nie podważył on niekaralności oprawców ani nie unieważnił wyroków trybunałów wojskowych i decyzji rad wojennych, choć jego twórcy zadeklarowali nielegalność tych instytucji. Regulacja ta przewiduje również usuwanie z przestrzeni publicznej symboli frankizmu oraz przedmiotów propagujących wojnę domową i dyktaturę. Jeszcze w trakcie prac nad ustawą 52/2007 za jedną z pilnych spraw uznano uporządkowanie sytuacji wokół Doliny Poległych ${ }^{41} .28$ maja 2011 roku utworzona została specjalna Komisja Ekspertów ds. Przyszłości Doliny Poległych, działająca przy Radzie Ministrów ${ }^{42}$. W jej raporcie z 28 listopada tego samego roku stwierdzono w punkcie 15, że

Ich obecność [szczątków generała Franco - M.K.J.] w bazylice jest przede wszystkim niezgodna z pierwotnym celem budowy Doliny, która miała służyć jako miejsce spoczynku osób poległych w czasie wojny. Jego pochówek wśród zmarłych i ofiar wojny domowej wypacza pierwotne znaczenie pomnika. Komisja nie ma też żadnych dowodów na to, że pochowanie Franco w Dolinie Poległych było życzeniem jego lub jego rodziny. Ponadto obecność w Bazylice szczątków generała Franco utrudnia realizację celu, jakim jest uczynienie z kompleksu miejsca pamięci ofiar wojny domowej, bez żadnych innych konotacji ideologicznych czy politycznych ${ }^{43}$.

W związku z powyższym Komisja w punkcie 31 swego raportu zarekomendowała przeniesienie szczątków generała Franco we wskazane przez jego rodzinę miejsce lub do innej lokalizacji, która zostanie uznana za godną i najbardziej odpowiednią, co powinno nastąpić przy szerokim porozumieniu parlamentarnym i akceptacji ze strony Kościoła katolickiego ${ }^{44}$. Inną ważną okolicznością było

40 Ustawa ta nie zadowoliła wszystkich. Określano ją jako „, mixture of grand symbolic gestures with smaller measures and full of soft law provisions". Zob. J.L. de la Cuesta, M. Odriozola, Historical Memory: The Spanish Legal Approach, „Journal of Comparative Law” 2018, nr 13, s. 116. Zob. też L. Ryan, Memory, Transnational Justice, and Recession in Contemporary Spain, „European Review” 25, 2016, nr 2, s. 295; J. Chaves-Palacios, op. cit., s. 535.

41 Dolina Poległych uważana jest za największy cmentarz wojny domowej. Zgodnie z badaniami z 2011 roku szacuje się, że w latach 1959-1983 przeniesiono tam 33847 ciał. Zob. Informe de la Comisión de Expertos sobre el Futuro del Valle de los Caidos, 28 listopada 2011 roku, s. 10-11, https://digital.csic.es/bitstream/10261/85710/1/INFORME\%20COMISION\%20EXPERTOS\%20 VALLE\%20CAIDOS\%20PDF.pdf (dostęp: 30.09.2021).

42 Orden PRE/1396/2011, de 27 de mayo, por la que se publica el Acuerdo de Consejo de Ministros por el que se crea la Comisión de Expertos para el Futuro del Valle de los Caídos, BOE z dnia 28 maja 2011 r. Nr 127, poz. 9320.

43 Zob. Informe de la Comisión..., s. 13.

44 Zob. ibidem, s. 21. Podobne stanowisko Komisja zajęła w sprawie szczątków José Antonia Primo de Rivery, które także znajdują się w Bazylice. Zob. jednak zdanie odrębne do raportu trzech członków Komisji, którzy nie poparli rekomendacji 36, dotyczącej przeniesienia grobu generała Franco. Ibidem, s. 25-26. 
również stanowisko instytucji międzynarodowych. W dotyczącym Hiszpanii sprawozdaniu działającej w ramach Organizacji Narodów Zjednoczonej Grupy Roboczej ds. Wymuszonych Zaginięć zalecono rozważenie i implementowanie rekomendacji przedstawionych przez Komisję Ekspertów ds. Przyszłości Doliny Poległych, przy jednoczesnym zachowaniu szerokiego konsensusu polityczne$\mathrm{go}^{45}$. Także w sprawozdaniu specjalnego sprawozdawcy w sprawie propagowania prawdy, sprawiedliwości, zadośćuczynienia i gwarancji niepowtarzania się czynów ${ }^{46}$, Pabla de Greiffa, zaaprobowano podjęcie względem Doliny Poległych działań na rzecz promocji prawdy i pamięci oraz wyjaśnienia kontekstu socjologiczno-politycznego tego miejsca, w którym wciąż przeważała symbolika frankistowska i faszystowska. W dokumencie tym zwrócono też uwagę, że „Trudno jest myśleć o niej [Dolinie Poległych - M.K.J.] jako o miejscu pokoju i pojednania, dopóki milczenie dominuje nad faktami dotyczącymi kontekstu i pochodzenia tego miejsca, a w szczególności dopóki grób dyktatora z kwiatami pozostaje w centrum pomnika" ${ }^{7}$. Zarówno raport Komisji Ekspertów, jak i oba wskazane sprawozdania zostały przywołane $\mathrm{w}$ preambule królewskiego dekretu-ustawy $10 / 2018$. W akcie tym zaznaczono też, że procedura w sprawie ekshumacji i przeniesienia szczątków dyktatora Francisca Franco uwzględnia interesy zainteresowanych stron, zarówno publiczne, jak i prywatne, zapewnia im prawo do wysłuchania, udział w postępowaniu i możliwość zaskarżenia działań administracyjnych przed właściwymi organami sądowymi, gwarantuje też zachowanie godności i szacunku, tak dla szczątków zmarłego, jak i jego krewnych. W istocie wszystkie te elementy zostały uregulowane $\mathrm{w}$ ustawie i zapewnione $\mathrm{w}$ trakcie trwającego postępowania. Hiszpański Trybunał mógł przywołać powyższe okoliczności w uzasadnieniu swojego postanowienia, co zdecydowanie wzmocniłoby jego wydźwięk, wskazując na właściwe wyważenie pozostających w konflikcie dóbr - z jednej strony interesu publicznego, z drugiej prawa skarżących. Względy bezpieczeństwa i porządek publiczny, w tym ryzyko ewentualnych zamachów terrorystycznych, spowodowały, że rząd, bazując na opracowaniach ekspertów, nie wyraził zgody na pochowanie szczątków Franco w krypcie katedry Almude$\mathrm{na}^{48}$. Świątynia ta znajduje się w centrum Madrytu i jest otwarta dla publiczności. Rząd chciał też uniknąć sytuacji, w której w przyszłości miejsce to przekształciłoby się w symbol powstania zbrojnego, wojny domowej oraz represji z czasów

45 Informe del Grupo de Trabajo sobre las Desapariciones Forzadas o Involuntarias (Misión a España), 2 lipca 2014 roku, Rada Praw Człowieka, A/HRC/27/49/Add.1, s. 19.

46 Informe del Relator Especial sobre la promoción de la verdad, la justicia, la reparación y las garantías de no repetición, Pablo de Greiff (Misión a España), 2 lipca 2014 roku, Rada Praw Człowieka, A/HRC/27/56/Add.1, s. 8-9.

47 „Dificilmente podrá pensarse como un lugar en favor de la paz y la reconciliación, mientras predomine el silencio sobre los hechos relevantes al contexto y origen del sitio, y en particular mientras siga en el centro del monumento la tumba con flores del dictador". Zob. Informe del Relator..., s. 8-9.

48 Krypta należy do rodziny Franco i spoczywają w niej rodzice skarżących. 
dyktatury ${ }^{49}$. Na skutek niewskazania przez krewnych Franco w wyznaczonym terminie innego miejsca pochówku rząd, stosownie do postanowień dekretu-ustawy $10 / 2018$, dokonał wyboru w tej sprawie. Decyzja ta była jednak zaskarżalna i stanowiła przedmiot oceny Sądu Najwyższego, który uznał, że nie była ona ani arbitralna, ani nieproporcjonalna.

Należy przy tym podkreślić, że zarówno prawo hiszpańskie, jak i prawo europejskie, w tym Konwencja o ochronie praw człowieka i podstawowych wolności, nie gwarantują krewnym bezwarunkowego uprawnienia do dysponowania ciałem bliskiej zmarłej osoby. Decyzja w sprawie miejsca pochówku nieżyjącego członka rodziny nie jest uprawnieniem bezwarunkowym, ale może być ograniczona $\mathrm{z}$ uwagi na interes publiczny wyrażony w normie prawnej rangi ustawowej. Podobnie wygląda sprawa, gdy chodzi o kwestię sprzeciwienia się przeprowadzeniu ekshumacji. Może bowiem istnieć interes publiczny, który to postępowanie uzasadnia. W sprawie Solska i Rybicka v. Polska ${ }^{50}$, jedynej jak do tej pory odnoszącej się do kwestii przeprowadzenia ekshumacji wbrew woli rodziny, ETPCz uznał, że przeprowadzona mimo sprzeciwu rodziny ekshumacja szczątków zmarłych mężów skarżących kobiet mogła być postrzegana jako uderzająca w sferę relacji w taki sposób i w takim stopniu, że wskazuje to na ingerencję w prawo do poszanowania życia prywatnego i rodzinnego. Trybunał strasburski ustalał zatem, czy tego rodzaju ingerencja była uzasadniona. Organ ten nie wykluczył, że w pewnych sytuacjach mogą zachodzić okoliczności, w których ekshumacja jest uzasadniona pomimo sprzeciwu rodziny ${ }^{51}$. Z kolei w sprawie Elli Poluhas Dödsbo v. Szwecja ${ }^{52}$ skarżąca podniosła zarzut naruszenia art. 8 Konwencji z uwagi na odmowę udzielenia jej zezwolenia na przeniesienie urny z prochami męża na cmentarz w Sztokholmie, na którym byli pochowani jej rodzice. Zarówno władze administracji publicznej, jak i sądy badające sprawę odrzuciły jej wniosek, odwołując się do prawa zmarłego do ,spokojnego odpoczynku”. Szwedzkie prawo w wyjątkowych okolicznościach pozwala przenieść szczątki lub prochy nieżyjącej osoby do innego grobu. Zgodnie z objaśnieniami do ustawy pogrzebowej, rozpatrując wniosek w tej sprawie, należy kierować się życzeniami wyrażonymi przez zmarłego za życia. Przyjmuje się też, że jeżeli takie życzenie zostało wyrażone, to zostało uwzględnione podczas pochówku. Najważniejszym warunkiem dopuszczenia przeniesienia jest to, aby nie było ono sprzeczne z preferencjami zmarłego. Ponadto zwykle wymagany jest jakiś związek między daną osobą a planowanym miejscem przeznaczenia ${ }^{53}$. Sądy szwedzkie, analizując ustawowe przesłanki ustaliły, że mąż skarżącej nie miał bliższego naturalnego związku

49 Problemas de seguridad y orden público derivados de la inhumación de Esteban en la Cripta de la Catedral de la Almudena, documento $n .{ }^{\circ} 132$, zob. uzasadnienie wyroku SN Królestwa Hiszpanii z 30 września 2019 roku, sygn. akt STS 2834/2019, s. 19-20.

50 Solska i Rybicka..., § $110 \mathrm{n}$.

51 Ibidem, § 121.

52 Elli Poluhas Dödsbo v. Szwecja, skarga 61564/00, wyrok ETPCz z 17 stycznia 2006 roku.

53 Ibidem, § 13. 
ze Sztokholmem. W dodatku nie przedstawiono żadnych innych powodów, które mogłyby usprawiedliwić zakłócenie spokoju grobu po upływie trzydziestu czterech lat. W tej sprawie ETPCz nie stwierdził jednak naruszenia art. 8 Konwencji. Jego ocena koncentrowała się na badaniu, czy ingerencja państwa była $\mathrm{w}$ tym wypadku zasadna w świetle art. 8 ust. 2 Konwencji, a dokładniej, czy władze i sądy krajowe miały prawo uznać, że odmowa zezwolenia na usunięcie urny była „konieczna w społeczeństwie demokratycznym” dla zapobieżenia zakłócenia porządku, ochrony moralności lub ochrony praw innych osób. Wymagało to wyważenia interesu jednostki do dysponowania urną z interesem społecznym $\mathrm{W}$ zapewnieniu świętości grobów (sanctity of graves) ${ }^{54}$. Trybunał strasburski przyznał, że jest to tak ważna i delikatna kwestia, że państwom należy przyznać szeroki margines oceny. Uznał ponadto, że szwedzkie władze wzięły pod uwagę wszystkie istotne okoliczności i starannie je rozważyły, a podane przez nie powody odmowy przeniesienia urny były istotne i wystarczające. Warto tutaj przywołać również sprawę Drašković v. Czarnogóra, która dotyczyła rodzinnego sporu na temat przeprowadzenia ekshumacji szczątków zmarłego i ich przeniesienia do innego grobu. ETPCz stwierdził, że w tym przypadku doszło do naruszenia art. 8 Konwencji, ponieważ władze krajowe nie wywiązały się z ciążącego na nich pozytywnego obowiązku wyważania konkurujących interesów jednostek i stworzenia $w$ tym celu odpowiednich regulacji prawnych oraz zapewnienia ich należytego stosowania ${ }^{55}$. Trybunał badał zatem, czy istniały odpowiednie mechanizmy prawne pozwalające zrównoważyć konkurujące interesy oraz czy interesy te zostały właściwe zidentyfikowane i odpowiednio wyważone ${ }^{56}$.

Nie mam wątpliwości co do tego, że rozstrzygnięcie hiszpańskiego Trybunału Konstytucyjnego było słuszne w kwestii oceny dopuszczalności ingerencji i jej proporcjonalności oraz w świetle standardów strasburskich. Rząd Hiszpanii miał prawo zdecydować o miejscu pochówku dyktatora $\mathrm{z}$ uwagi na okoliczności sprawy, jej kontekst społeczno-polityczny, w tym również międzynarodowy, oraz wzgląd na pamięć ofiar wojny domowej i reżimu. Decyzja ta miała podstawy w przepisach prawa i była uzasadniona społecznie. Interes publiczny został należycie wyważony $\mathrm{z}$ interesem prywatnym. Zapewniono przy tym należyte gwarancje proceduralne. Jednak hiszpański Trybunał wpadł przy tym w pułapkę, którą sam na siebie zastawił. Zrobił więcej, niż musiał, a jednak zbyt mało. Co prawda, odrzucenie skargi konstytucyjnej nie wymagało uzasadnienia, jednak Trybunał, decydując się na jego sporządzenie, powinien dołożyć starań, aby było ono możliwie najlepiej umotywowane i przekonujące. Sprawa tego rodzaju, jej precedensowy charakter, waga i znaczenie wymagały właśnie takiej pogłębionej argumentacji.

\footnotetext{
54 Ibidem, $\S 25$.

55 Drašković v. Czarnogóra, skarga nr 40597/17, wyrok ETPCz z 09 września 2020 roku, $§ 50$.

56 Ibidem, $\$ 55$.
} 


\section{Bibliografia}

\section{Literatura}

Chaves-Palacios J., Consecuencias del franquismo en la España democrática: legislación, exhumaciones de fosas y memoria, „Historia Contemporánea” 2019, $\mathrm{nr} 60$.

De la Cuesta J.L., Odriozola M., Historical Memory: The Spanish Legal Approach, „Journal of Comparative Law" 2018, nr 13.

Espín Templado E., [w:] Derecho constitucional, vol. 1. El ordenamiento constitucional. Derechos $y$ deberes de los ciudadanos, ed. L. López Guerra et al., Valencia 2013.

European rights court rejects bid to halt Franco's exhumation, https://www.france24.com/ en/20191017-european-rights-court-rejects-bid-to-halt-franco-s-exhumation.

Franco's grandchildren take Strasbourg a lawsuit for the exhumation of the dictator, https://spains news.com/francos-grandchildren-take-strasbourg-a-lawsuit-for-the-exhumation-of-the-dictator/.

Humphrey M., Law, Memory and Amnesty in Spain, „Macquarie Law Journal” 2014 , nr 13, baza HeinOnline, https://heinonline.org/HOL/P?h=hein.journals/macq13\&i=33.

Informe de la Comisión de Expertos sobre el Futuro del Valle de los Caídos, 28 listopada 2011 roku, https://digital.csic.es/bitstream/10261/85710/1/INFORME\%20COMISION\%20EXPER TOS\%20VALLE\%20CAIDOS\%20PDF.pdf.

Informe del Grupo de Trabajo sobre las Desapariciones Forzadas o Involuntarias (Misión a España), 2 lipca 2014 roku, Rada Praw Człowieka, A/HRC/27/49/Add.1.

Informe del Relator Especial sobre la promoción de la verdad, la justicia, la reparación y las garantías de no repetición, Pablo de Greiff (Misión a España), 2 lipca 2014 roku, Rada Praw Człowieka, A/HRC/27/56/Add.1.

Kłopocka-Jasińska M., Skarga konstytucyjna w Królestwie Hiszpanii. W poszukiwaniu optymalnej ochrony skargowej, Warszawa 2010.

Mołdawa T., System konstytucyjny Hiszpanii, Warszawa 2012.

Pulido Quecedo M., La Constitución Española con la Jurisprudencia del Tribunal Constitucional, Pamplona 1996.

Roca Trías E., Ahumada Ruiz M.A., Los principios de razonabilidad y proporcionalidad en la jurisprudencia constitucional española, Rome 2013, https:/www.tribunalconstitucional.es/es/ trilateral/documentosreuniones/37/ponencia\%20espa\%C3\%91a\%202013.pdf.

Ryan L., Memory, Transnational Justice, and Recession in Contemporary Spain, „European Review" 25, 2016, nr 2.

Sadurski W., Supranational Public Reason: Part One - A Theory, „Sydney Law School Research Paper" 2015, nr 15/02, https://ssrn.com/abstract=2553611.

Śledzińska-Simon A., Analiza proporcjonalności ograniczeń konstytucyjnych praw $i$ wolności. Teoria i praktyka, Wrocław 2019.

Utrilla D., On exhumation of human remains: Strasbourg's standards, EU Law Live, 11 czerwca 2020 roku, https://www.academia.edu/43448767/On_exhumation_of_human_remains_Strasbourg_s_standards.

\section{Akty prawne}

Ley Orgánica 2/1979, de 3 de octubre, del Tribunal Constitucional, BOE z 5 października 1979 r. $\mathrm{Nr} 239$.

Ley de 23 septiembre 1939 por la cual se consideraban como no delictivos determinadas actuaciones políticas sociales desarrolladas desde el 14 de abril de 1931 hasta el 18 de julio de 1936, BOE z dnia 30 września 1939 roku, nr 278. 
Ley 46/1977, de octubre, de Amnistía, BOE z dnia 17 października 1977 r. Nr 248.

Ley $52 / 2007$, de 26 de diciembre, por la que se reconocen y amplían derechos y se establecen medidas en favor de quienes padecieron persecución o violencia durante la guerra civil y la dictadura, BOE z 27 grudnia 2007 r. Nr 310.

Orden PRE/1396/2011, de 27 de mayo, por la que se publica el Acuerdo de Consejo de Ministros por el que se crea la Comisión de Expertos para el Futuro del Valle de los Caídos, BOE z 28 maja 2011 r. Nr 127, poz. 9320.

Real Decreto-ley 10/2018, de 24 de agosto, por el que se modifica la Ley 52/2007, de 26 de diciembre, por la que se reconocen y amplían derechos y se establecen medidas en favor de quienes padecieron persecución o violencia durante la Guerra Civil y la Dictadura, BOE z 25 sierpnia 2018 r. Nr 206.

\section{Orzecznictwo}

Drašković v. Czarnogóra, skarga 40597/17, wyrok ETPCz z 9 września 2020 roku.

Elli Poluhas Dödsbo v. Szwecja, skarga 61564/00, wyrok ETPCz z 17 stycznia 2006 roku.

Postanowienie Trybunału Konstytucyjnego Królestwa Hiszpanii z 17 października 2020 roku, sygn. akt ATC 119/2020, ECLI:ES:TC:2019:119A.

Problemas de seguridad y orden público derivados de la inhumación de Esteban en la Cripta de la Catedral de la Almudena, documento n. ${ }^{\circ} 132$ - uzasadnienie wyroku Sądu Najwyższego Królestwa Hiszpanii z 30 września 2019 roku, sygn. akt STS 2834/2019.

Solska i Rybicka v. Polska, skargi 30491/17 i 31083/17, wyrok ETPCz z 20 września 2018 roku.

Wyrok Sądu Najwyższego Królestwa Hiszpanii z 30 września 2019 roku, sygn. akt STS 2834/2019, ECLI: Es:Ts:2019:2834, https://www.poderjudicial.es/search/openDocument/c8a2fa5486ced8af.

Wyrok Trybunału Konstytucyjnego Królestwa Hiszpanii z 1 lutego 2016 roku, sygn. akt STC $11 / 2016$.

Wyrok Trybunału Konstytucyjnego Królestwa Hiszpanii z 25 czerwca 2009 roku, sygn. akt STC $155 / 2009$. 